\title{
Predictive factors of severe perioperative morbidity of Radical Hysterectomy with lymphadenectomy in Early- stage cervical Cancer: A French prospective multicentric cohort of 248 patients
}

\author{
Balaya V. ${ }^{1,2,3 *}$, Mathevet $\mathrm{P}^{4}$, Magaud L. ${ }^{5}$, Delomenie M. ${ }^{1,3}$, Bonsang-Kitzis $\mathrm{H}{ }^{1,3}$, Ngô $\mathrm{C}^{1,{ }^{1,3}}$, Huchon $\mathrm{C} .{ }^{6}$, \\ Bats AS. ${ }^{1,3}$, Lecuru F.,
}

1. Gynecologic and Breast Oncologic Surgery Department, Georges Pompidou European

Hospital, Paris, France

2. URDIA Anatomy EA 4465 UFR Biomédicale des Saints-Pères, Paris, France

3. Paris Descartes University, Sorbonne Paris Cité, Faculty of Medicine, Paris, France

4. Gynecology Department, University Hospital, University of Lausanne, Lausanne, Switzerland.

5. Hospices Civils de Lyon, Pôle IMER, Lyon, F-69003, France

6. Obstetrics and gynecology department, Poissy UMC, France

${ }^{*}$ Correspondence to

Vincent BALAYA MD, MSc

Service de Chirurgie Cancérologique, Gynécologique et du Sein

Hôpital Européen Georges Pompidou

20, rue Leblanc

75908 Paris Cedex 15

France

Phone : + $33(0) 684947080$

Fax : +33 (0)156092582

E-mail: vbalaya@hotmail.com

Declaration of interest: None

Short running title: Morbidity of radical hysterectomy: A French prospective multicentic cohort of 248 patients

Predictive factors of severe perioperative morbidity of Radical Hysterectomy with lymphadenectomy in Early-stage cervical Cancer: A French prospective multicentric cohort of 248 patients 


\section{Abstract}

Objective: The purpose of this study was to assess the postoperative morbidity after radical hysterectomy $(\mathrm{RH})$ for early-stage cervical cancer and to determine risk factors of severe perioperative morbidity.

Methods: Data of two prospective trials on sentinel node biopsy for cervical cancer (SENTICOL I \& II) were analysed. Patients having a radical hysterectomy were included between 2005 and 2012 from 25 French oncologic centers. Postoperative complications were prospectively recorded in a pre-specified analysis.

Results: 248 patients met the inclusion criteria. The median age was 44.5 years [ $25-85$ ]. $88.7 \%$ of patients had a stage IB1 disease. There were $71.4 \%$ epidermoid carcinomas and $25 \%$ adenocarcinomas. 125 patients $(50.4 \%)$ had a laparoscopic-assisted vaginal $\mathrm{RH}, 88$ patients $(35.5 \%)$ had a total laparoscopic $\mathrm{RH}, 26$ patients (10.5\%) had an open $\mathrm{RH}$ and 9 patients (3.6\%) had a roboticassisted $\mathrm{RH}$. Sixteen patients $(6.4 \%)$ had intraoperative complications. On a multivariate analysis, intraoperative complications were significantly associated with BMI $>30 \mathrm{~kg} / \mathrm{m}^{2}$. The urinary, lymphovascular and neurologic complications rates were respectively $34.3 \%, 20.6 \%$ and $19.8 \% .31$ patients $(12.5 \%)$ had severe postoperative complications (Clavien-Dindo $\geq 3$ or CTCAE $\geq 3$ ). On multivariate analysis, severe postoperative complications were associated with parametrial involvement, preoperative brachyherapy and inclusion in low surgical skills center.

Conclusions: This study based on prospective data showed that $\mathrm{RH}$ has low severe postoperative complications. The main complications were urinary infections and lower limb lymphedema. Patients with early-stage cervical cancer should be referred to expert center to ensure best surgical outcomes.

\section{Keywords: "Cervical cancer", "Surgery", "Morbidity", "Complications", "Radical} Hysterectomy" 


\section{Introduction}

Cervical cancer is the second most common cancer among women and the third cause of cancer-related deaths in females with approximately 527600 new cases and 265700 deaths each year (1). According to main guidelines $(2,3)$, surgery is the preferred option for early-stage cervical cancer (IB1 to IIA1 FIGO stage), especially in young patients.

Radical hysterectomy $(\mathrm{RH})$ consists in the resection of the uterus, the cervix and the upper vagina associated with resection of the parametrial tissues. The extent of the parametrectomy should be tailored according to the tumor characteristics. Today the majority of operations proposed to the patients are $\mathrm{B} 1$ to $\mathrm{C} 1 \mathrm{RH}$ according to the Querleu-Morrow classification (4). Pelvic lymphadenectomy (PLN) is associated to $\mathrm{RH}$, and sentinel lymph node biopsy (SLN) has been introduced more recently. This procedure is mostly performedby minimally invasive surgery for 20 years.

Although 5-year survival rates of $88-97 \%$ have been reported, RH-PLN is associated with several significant complications such as urinary, lymphovascular, neurologic and digestive morbidity which noticeably affects the quality of life of the patients (5-7). The actual rate of complications could be underestimated because only $5 \%$ of patients with this problem seek medical care for this reason (8) and because most data come from old or retrospective studies.

The aim of our study was to assess the morbidity of radical hysterectomy and nodal staging for early-stage cervical cancer, in the modern era, with multicentric prospective data.

\section{Materials and Methods}

The main objective was to describe per and postoperative complications of RH-PLN. The secondary objective was to determine risk-factors of complication.

\section{Population study}


We performed an ancillary study on the database of two prospective multicentric studies on sentinel lymph node (SLN) biopsy (SENTICOL I and II). Design of the both studies have already been described elsewhere $(9,10)$. In both studies, postoperative complications were prospectively recorded in a pre-specified analysis.

We performed a retrospective analysis of the two databases. We included cases with a radical hysterectomy. Patients who didn't undergo surgery, had tracheclectomy or simple hysterectomy, were excluded. This study was approved by the Paris Descartes CPP (Ethical Committee). Patients included in the two studies signed an informed consent stating the use of data for secondary analyses.

\section{Data analysis}

For each patient, we extracted demographic characteristics, surgical history, and clinical data including FIGO stage. Operative records were reviewed, and data about the type of surgical approach, the type of hysterectomy performed according to the Querleu-Morrow classification, the type of lymph node staging (SLN biopsy only or additional pelvic lymphadenectomy), were collected. Pathological data was reviewed (tumor histology, lymphovascular space invasion, nodal status, number or removed nodes, parametrial status, vaginal margin status, surgical margin status and tumor size).

We used the Clavien-Dindo classification to assess the severity of early postoperative complivations ( $\leq 30$ days after surgery) and the CTCAE classification $\vee 4.03$ for late postoperative complications ( $>30$ days after surgery) (11). A severe complication was defined as grade $\geq 3$ in the Clavien-Dindo classification or as grade $\geq 3$ in the CTCAE classification.

We categorized 3 types of inclusion center according to the number of patients included and level of experience: type 1 (<10 patients, 18 centers), type 2 (10 to 20 patients, 3 centers) and type 3 (>20 patients, 4 centers).

\section{Statistical analysis}

Qualitative variables were expressed as $\mathrm{n}(\%)$ and quantitative data as mean [range]. Patients were categorized into two groups according to the presence or the absence of complications. An univariate analysis was performedto identify risk factors of intraoperative and severe postoperative complications. We applied the chi-square test (or Fisher's test if the sample size was too small) to compare qualitative variables and the Student's t test to compare quantitative variables. 
Variables yielding $p$ values lower than 0.2 by univariate analysis were entered into a multivariate logistic regression model to determine variables independently associated with intraoperative and severe postoperative complications of radical hysterectomy. Values of $p$ lower than 0.05 were considered as significant.

Overall survival and free-recurrence survival were analysed by using Kaplan-Meier analysis and compared by applying log-rank test.

Data were recorded in an Excel files and statistical analyses were performed using XLStat software (Addlnsoft V19.4).

\section{Results}

Between January 2005 and July 2012, 412 patients have been enrolled in SENTICOL I and SENTICOL II studies. 248 patients from 25 patients were finally included in the present study (Figure 1).

\section{Patient and surgery characteristics}

The median age was 44.5 years [25 - 85] and the median Body Mass Index (BMI) was 22.9 $\mathrm{kg} / \mathrm{m}^{2}$ [14.6 - 45]. 63 patients (25.4\%) were included in type 1, 35 patients (14.1\%) in type 2 and 150 patients $(60.5 \%)$ in type 3 center. Most of the patients had FIGO stage IB1 disease (88.7\%). 150 patients $(60.5 \%)$ had a previous conisation. The majority of patients had squamous cell carcinoma (71.4\%), 62 patients had adenocarcinoma (25\%), 4 patients had adenosquamous carcinoma (1.6\%) and one patient had adenoid kystic carcinoma (0.4\%). At preoperative imaging, the median size of the tumor was $15 \mathrm{~mm}$ [0-50] and the tumor was larger than $20 \mathrm{~mm}$ in $35.1 \%$ of cases. 75 patients had a preoperative brachytherapy $(30.2 \%)$. The sociodemographic and clinical characteristics are shown in Table 1.

Most patients $(84.7 \%)$ had a type B procedure. Minimal invasive surgery was the main surgical approach (222 patients, 89.5\%) whereas 26 patients have been operated on by laparotomy (10.5\%). 30 patients $(12.1 \%)$ were operated in two-steps by laparoscopy (First intervention for lymph node staging then a second intervention for radical hysterectomy).

75 patients $(30.2 \%)$ had a SLN biopsy alone, 157 patients $(63.3 \%)$ had an additional pelvic 
lymphadenectomy and 16 patients also had a paraaortic lymphadenectomy (6.5\%). The median number of removed SLN per patient was 3 [1-11]. In case of additional pelvic or paraaortic lymphadenectomy, the mean number of removed non-SLN per patient was 13 [3-72] (Table 1). Thirty patients had at least one positive lymph node (12.1\%).

At final pathologic examination, $17.7 \%$ of patients had a tumor size larger than $20 \mathrm{~mm}$. There were a parametrial spread in $4 \%$ of cases, a vaginal spread in $4.8 \%$ and positive surgical margin in $4.8 \%$. Forty-six patients received adjuvant radiotherapy (18.1\%).

\section{Intraoperative complications}

Sixteen patients $(6.4 \%$.) had an intraoperative complication. Bladder was injured in 5 cases (2\%) and ureter was injured in 2 cases $(0.8 \%)$. Iliac artery injury during the pelvic lymphadenectomy occurred in 4 cases (1.6\%) and in one case laparoconversion was necessary. No bowel injury was reported. In one case, uterus has been perforated after intrauterine cannulation due to postbrachytherapy cervical stenosis. A non-optimal patient positioning was responsible of intraoperative complications in 4 cases $(1.6 \%)$ (one case of brachial plexus compression, one case of external popliteal sciatic nerve compression, one case of rhabdomyolisis and one case of compressive slough). Three of these complications occurred with a laparoscopic approach (Table 2).

In univariate analysis, intraoperative complications were more common in patients who have been operated on by laparotomy rather than by minimal invasive techniques $(37.5 \%$ vs $8.6 \%, p=$ 0.007). Compared to patients who were operated by MIS approach, patients who were operated by laparotomy were significantly older (mean age: $53.9 \pm 17.1$ years vs $46.4 \pm 11.5$ years, $p=0.003$ ) and had an higher BMl $\left(27.2 \pm 4.8 \mathrm{~kg} / \mathrm{m}^{2}\right.$ vs $\left.23.9 \pm 5.5 \mathrm{~kg} / \mathrm{m}^{2} \mathrm{p}=0.003\right)$.

Intraooperative complications were associated with a tumor size $\geq 20 \mathrm{~mm}(46.7 \%$ vs $17.3 \%, p=$ $0.005)$, parametrial spread $(21.4 \%$ vs $3.1 \%, p=0.001)$ and vaginal invasion $(28.6 \%$ vs $3.6 \%, p<$ 0.0001). In the group of patients with no intraoperative complications, patients had a significant lower BMI (Mean of $23.9 \mathrm{~kg} / \mathrm{m}^{2} \mathrm{vs} 28.4 \mathrm{~kg} / \mathrm{m}^{2}, \mathrm{p}=0.001$ ) (Table 3).

In multivariate analysis, only $\mathrm{BMI}>30 \mathrm{~kg} / \mathrm{m}^{2}$ was identified as an independent risk factor of intraoperative complications $(\mathrm{ORa}=4.9,95 \% \mathrm{Cl}=[1.72-20.44], \mathrm{p}=0.02)$. Open approach seemed to be associated with more intraoperative complications than minimal invasive approach but didn't reach statistical significance $(\mathrm{ORa}=3.64,95 \% \mathrm{Cl}=[0.76-17.55], \mathrm{p}=0.11)$.

\section{Postoperative complications}


Overall, severe postoperative complications (defined as Clavien-Dindo $\geq 3$ and/or CTCAE $\geq 3$ ) were reported in 31 patients (12.5\%), 120 patients (48.4\%) had non-severe complications and 97 patients (39.1\%) were free of complications. Overall complications are summarized in Table 2.

The urinary complications were the most frequent postoperative complications with 106 events in 85 patients $(34.3 \%)$. Most of them were minor urinary infection which occurred in 37 patients (14.9\%). Dysuria was observed in 17 patients $(6.9 \%)$ and urinary retention in 12 patients $(4.8 \%)$. Severe complications consisted in uretero-vesical fistula in 4 patients (1.6\%), vesico-vaginal fistula in 3 patients (1.2\%) and hydronephrosis due to a unilateral ureteral stenosis in 3 patients $(1.2 \%)$.

51 patients $(20.6 \%)$ had 56 lymphovascular complications. The main complication was lower limbs lymphedema, which was bilateral in 20 cases (8.1\%) and unilateral in 16 cases (6.5\%). In 17 cases $(6.8 \%)$, lower limbs lymphedema were assessed as grade II in the CTCAE classification. Fourteen patients had a pelvic lymphocele (5.6\%). Three patients $(1.2 \%)$ had a pelvic lymphocele which necessitated a radiologic drainage (Clavien-Dindo class III).

49 patients (19.8\%) had 52 non-severe neurologic complications. We recorded 25 cases of genitofemoral nerve injury (bilateral in 9 cases and affected only sensitivity in 11 cases). We recorded 23 cases of obturator nerve injury (bilateral in 7 cases and was exclusively sensitive in 10 cases). No patients had severe postoperative neurologic complication.

Two patients $(0.8 \%)$ had a peritonitis and two patients $(0.8 \%)$ had a pelvic deep abscess. Two patients $(0.8 \%)$ had a herniation through the ombilical scar (one was complicated of hernial stricture). One patient, with a known hepatic cirrhosis due to HCV infection and HIV co-infection, had liver decompensation 3 weeks after surgery. 11 patients (4\%) had complete vaginal cuff dehiscence, whose 5 after a sexual intercourse and 5 patients had a vaginal scar necrosis (2\%). One patient had a pulmonary embolism and one a lower limb vein thrombosis.

In the subgroup of 76 patients (30.2\%) who had preoperative brachytherapy, 14 patients had severe postoperative complications (18.4\%) and this rate seemed to be higher than in patients with no preoperative brachytherapy $(18.4 \%$ vs $11.5 \%, p=0.08)$. There were no differences between patients with and without preoperative brachytherapy in terms of urinary complications $(38.2 \%$ vs $33.9 \%, p=$ $0.52)$ and neurologic complications $(19.7 \%$ vs $20 \%, p=0.96)$ but lymphovascular complications were more frequent in patients with preoperative brachytherapy than in patients without preoperative brachytherapy (28.9\% vs $17 \%, p=0.03)$. 
In univariate analysis, no variable was significantly associated with severe postoperative complications. However, patients with severe postoperative complications seemed to have more parametrial invasion $(9.7 \%$ vs $3.3 \%, p=0.1)$ (Table 4). Patients who have been operated in type 3 inclusion center seemed to have less severe postoperative complications (13/150 patients, $8.7 \%)$ than patients from type 2 and 1 inclusion center (respectively 5/35 patients, 14.3\% and 13/63 patients, $20.6 \%, p=0.052)$.

Multivariate analysis identified two risk-factors of severe postoperative complications: paramatrial invasion $(\mathrm{ORa}=7.39,95 \% \mathrm{IC}=[1.37-39.72], \mathrm{p}=0.02)$ and preoperative brachytherapy $(\mathrm{ORa}=3.98,95 \% \mathrm{IC}=[1.29-12.34], \mathrm{p}=0.016)$. Patients who have been operated in in type 3 center had lower risk of severe postoperative complications $(\mathrm{ORa}=0.2,95 \% \mathrm{IC}=[0.06-0.66], \mathrm{p}=0.008)$.

\section{Follow-up and oncologic outcomes}

The median follow-up was 49 months [0-130]. During follow-up, 13 patients (5.2\%) were lost to follow-up, 23 patients (9.8\%) had recurrent disease and 14 patients (6\%) died from cervical cancer. Among patients who had recurrence, 7 patients had a local recurrence, 5 patients had a metastatic lymph node, 1 patient had a locoregional metastasis and 10 patients had distant metastasis. The median-time of recurrence was 21 months [2- 72].

Overall survival and recurrence-free survival rates didn't significantly differ at 5-year of follow-up between group of patients without and group of patients with severe complications ( $94.6 \%$ vs $90.9 \%$, $p=0.72$ and $92.2 \%$ vs $86.1 \%, p=0.67$ respectively) (Figure 2).

\section{DISCUSSION}

Few prospective data about the morbidity of radical hysterectomy with nodal staging are available. To our best knowledge, the present study is the first study that precisely assesses riskfactor of intraoperative and postoperative severe morbidity after this procedure. Through this prospective cohort of 248 patients, we have shown that postoperative complications were significant and were mainly urinary (34.3\%), lymphovascular (20.6\%) and neurologic (19.8\%). However, the absolute rate of intraoperative complications $(6.4 \%)$ and severe postoperative morbidity $(12.1 \%)$ are 
finally low.

In this study, obesity, defined as BMI $>30 \mathrm{~kg} / \mathrm{m}^{2}$, was significantly associated with a higher risk of intraoperative complications $(\mathrm{ORa}=4.9,95 \% \mathrm{Cl}=[1.72-20.44], \mathrm{p}=0.02)$. In a retrospective cohort of 497 patients who underwent laparoscopic surgery for gynecologic malignancie, Peng et al. didn't find any differences in intraoperative complication rates between non-obese, obese and morbid obese patients but the rates of major intraoperative complications were higher in obese and morbid obese patients group than in non obese patient (4.32\% and $8.51 \%$ respectively versus $2.78 \%)$ (12). Similarly, for Frumovitz et al., there were no statistical differences in terms of intraoperative complications between normal-BMI, overweight, obese and morbid obese patients $(6 \%, 4 \%, 6 \%$ and $6 \%$ respectively) but higher BMI was significantly correlated with higher estimated operative blood loss ( $p=$ $0.001)(13)$.

The type of surgical approach may have an impact on intraoperative complications. According to our results, open approach tends to be more at risk of intraoperative complication than minimal invasive approach. Safety and surgical benefits of MIS in treatment of early-stage cervical cancer have been described in the litterature. Although intraoperative complications rate were not statistically significant between open and MIS approach, median blood loss are significantly lower and median hospital stay shorter (14-16). Less postoperative complications are reported in case of MIS approach (17). However, results of the LACC trial which compared open, laparoscopic and robotic surgery for $\mathrm{RH}$ will provide prospective data (18).

Urinary complications are the most frequent complications. Most were urinary infection. Bladder dysfunction is a major concern after RH-PLN. Rates coming from literature (up to $85 \%$ ) are much higher than our $(19,20)$. Classically, two steps of vesical dysfunctions are described in the early postoperative period $(5,7)$. The first phase corresponds to a hypertonic one due to a spastic bladder with a low vesical compliance. This phase is usually transient during 8 to 12 weeks. In our study, this phase concerned 22 patients $(8.9 \%)$. The second phase is characterized by a hypotonic and overdistended bladder. This phase results from an inappropriate management during the postoperative period and affected 14 patients (5.6\%). An incomplete vesical voiding may result in lower urinary tract infection (33 patients, 13.3\%) and upper urinary tract infection (7 patients, 2.8\%). Long-term clinically significant bladder dysfunctions is the most common long-term complication of $\mathrm{RH}$ and occur in about 8 to $80 \%$ of patients $(7,19-24)$. These dysfunctions are lied to detrusor overactivity, 
increased bladder capacity and decreased bladder compliance (23) and concerned 6 patients (2.4\%), 6 months after surgery. Voiding effort may result in pelvic static trouble but only one patient $(0.4 \%)$ had a prolapse 6 months after surgery. Better selection of patients, use of less radical procedures, development of nerve-sparing $\mathrm{RH}$ may explain our results (25). Ureteral complications, fistula or stenosis, and bladder fistula are rare and estimated less than $2 \%(26-28)$. This rate was $2.8 \%(7$ patients) in our study.

In a retrospective cohort of 264 patients who underwent pelvic lymphadenectomy with or without paraaortic lymphadenectomy for gynecologic cancer, the rate of lower limb lymphedema was $23.1 \%$ one year after surgery (29) and higher than ours of $14.5 \%$. The authors found that this complication was associated with $\mathrm{BMI}>25 \mathrm{~kg} / \mathrm{m}^{2}$, adjuvant radiotherapy, the presence of a lymphocele and a full lymphadenectomy perfomed. In a cohort of 591 patients who underwent total hysterectomy and pelvic lymphadenectomy for endometrial cancer, Yost et al. found the same risk factors with an overall prevalence of lower limb lymphedema of $47 \%$ at 6.2 years of follow-up (30). In a prospective cohort of 292 patients with cervical cancer, Zikan et al. observed a lymphocele postoperative rate of $16.1 \%$, whose $5.8 \%$ were symptomatic (31). In our study, we found lower rate of $5.6 \%$ of postoperative lymphocele. This difference may be due to higher rate of paraaortic lymphadenectomy of $41.4 \%$ and a main surgical approach by laparotomy in $82.5 \%$ of cases whereas in our study, the paraaortic dissection rate was $6.5 \%$ and surgical approach by laparotomy rate was $10.5 \%$.

Neurologic complications are not directly linked to the $\mathrm{RH}$ itself but to pelvic lymphadenectomy. Irritation of the genitofemoral or obturator nerves may be induced by manipulation and direct thermal or electrical injury by monopolar diathermy. In a cohort of 1000 pelvic lymphadenectomy for gynecologic cancer, Querleu et al. observed 3 intraoperative obturator nerve injury, a genitofemoral nerve dysesthesia and a partial palsy of the psoas muscle (32). In a cohort of 80 patients who underwent radical hysterectomy by robot-assisted approach, Persson et al. described 8 genitofemoral nerve injuries (10\%) and one partial obturator nerve palsy (1.2\%) (33). In a review of the literatture, Kruijdenberg et al. found a neurologic complication rate of $3.4 \%$ after robotic-assisted $\mathrm{RH}$ and $2 \%$ after laparoscopic $\mathrm{RH}$ (34). Our results highlighted higher neurologic complications rates, and this may be explained by the prospective record of complications.

Our results showed better surgical outcomes if patients were referred to expert centers with high surgical skills. As recommended in the last ESGO guidelines, surgery should be performedby 
gynecologic oncologist and trained surgeon in a specialized team dedicated to management of gynecologic cancers (3). Treatment in expert center with a high-volume of surgical procedures has been highlighted in ovarian cancer (35) and was defined as quality indicators (36).

We found that preoperative brachytherapy was an independent risk-factor of severe postoperative morbidity. For intermediate and high-risk of early-stage cervical cancer, preoperative brachytherapy followed by surgery may be an acceptable option to primary surgery in order to decrease tumoral size and eradicate LVSI (3). In a cohort of 162 patients who underwent laparoscopic radical hysterectomy after receiving brachytherapy, Uzan et al. suggested that preoperative brachyhterapy didn't increase peri- and postoperative morbidity (37). However, they reported a severe morbidity rate of $20.4 \%$ (33/162 patients with grade IIIA or IIIB of the Clavien-Dindo classification) which was higher than our.

One of the limitations of this study is the retrospective analysis of two databases which were not designed to our specific objectives and therefore some details lacked, such as the mean blood loss or the need of urinary self-catheterisation. In our cohort, $84,7 \%$ of the radical hysterectomy were type B and complications rates may be more important in case of more aggressive radical hysterectomy. This may be associated with the important number of small cervical cancer in this series: $65 \%$ of patients had preoperative tumor size smaller than $2 \mathrm{~cm}$ and only $17 \%$ were bigger than $2 \mathrm{~cm}$ at the definitive histological examination. These rates may be explained by the inclusion criteria of SENTICOL I and SENTICOL II studies due to the exclusion of patients who had neoadjuvant radiotherapy or chemotherapy. The strengths of this study are that all data related to postoperative morbidity were prospectively recorded in a quality-checked database and population study was homogeneous with a long follow-up. Moreover, patients came from multiple institutions taking in account different levels of surgical expertise and different levels of learning curve.

\section{Conclusion}

This study using prospective data, confirms that radical hysterectomy has significant postoperative morbidity but low severe postoperative complications. The main complications were 
urinary infections and lower limb lymphedema. Incidence of complications is lower in experienced and patients with early-stage cervical cancer should be referred to expert center to ensure best surgical outcomes.

\section{REFERENCES}

1. Torre LA, Bray F, Siegel RL, Ferlay J, Lortet-Tieulent J, Jemal A. Global cancer statistics, 2012. CA Cancer J Clin. 2015 Mar;65(2):87-108.

2. Marth C, Landoni F, Mahner S, McCormack M, Gonzalez-Martin A, Colombo N. Cervical cancer: ESMO Clinical Practice Guidelines for diagnosis, treatment and follow-up. Ann Oncol. 2017 Jul 1;28(suppl_4):iv72-83.

3. Cibula D, Pötter R, Planchamp F, Avall-Lundqvist E, Fischerova D, Haie Meder C, et al. The European Society of Gynaecological Oncology/European Society for Radiotherapy and

Oncology/European Society of Pathology Guidelines for the Management of Patients With Cervical Cancer. Int J Gynecol Cancer. 2018 May;28(4):641.

4. Querleu D, Cibula D, Abu-Rustum NR. 2017 Update on the Querleu-Morrow Classification of Radical Hysterectomy. Ann Surg Oncol. 2017 Oct;24(11):3406-12.

5. Rob L, Halaska M, Robova H. Nerve-sparing and individually tailored surgery for cervical cancer. Lancet Oncol. 2010 Mar;11(3):292-301.

6. Raspagliesi F, Ditto A, Hanozet F, Martinelli F, Solima E, Zanaboni F, et al. Nerve-sparing radical hysterectomy in cervical cancer: evolution of concepts. Gynecol Oncol. 2007 Oct;107(1 Suppl 1):S119-121.

7. Laterza RM, Sievert K-D, de Ridder D, Vierhout ME, Haab F, Cardozo L, et al. Bladder function after radical hysterectomy for cervical cancer. Neurourol Urodyn. 2014 Feb 12;

8. Magrina JF, Pawlina W, Kho RM, Magtibay PM. Robotic nerve-sparing radical hysterectomy: feasibility and technique. Gynecol Oncol. 2011 Jun 1;121(3):605-9.

9. Lécuru F, Mathevet $P$, Querleu D, Leblanc E, Morice P, Daraï E, et al. Bilateral negative sentinel nodes accurately predict absence of lymph node metastasis in early cervical cancer: results of the SENTICOL study. J Clin Oncol Off J Am Soc Clin Oncol. 2011 May 1;29(13):1686-91.

10. Mathevet P, Lecuru F, Magaud L, Bouttitie F. Sentinel lymph node biopsy for early cervical cancer: Results of a randomized prospective, multicenter study (Senticol 2) comparing adding pelvic lymph node dissection vs sentinel node biopsy only. Gynecol Oncol. 2017 Jun;145, Supplement 1:23.

11. Dindo D, Demartines N, Clavien P-A. Classification of surgical complications: a new proposal with evaluation in a cohort of 6336 patients and results of a survey. Ann Surg. 2004 Aug;240(2):20513.

12. Peng J, Sinasac S, Pulman KJ, Zhang L, Murphy J, Feigenberg T. The Feasibility of Laparoscopic Surgery in Gynecologic Oncology for Obese and Morbidly Obese Patients. Int J Gynecol Cancer. 2018 Jun;28(5):967.

13. Frumovitz M, Sun CC, Jhingran A, Schmeler KM, Dos Reis R, Milam MR, et al. Radical hysterectomy in obese and morbidly obese women with cervical cancer. Obstet Gynecol. 2008 Oct;112(4):899-905.

14. Wright JD, Herzog TJ, Neugut Al, Burke WM, Lu Y-S, Lewin SN, et al. Comparative effectiveness of minimally invasive and abdominal radical hysterectomy for cervical cancer. Gynecol Oncol. 2012 Oct;127(1):11-7. 
15. Mendivil AA, Rettenmaier MA, Abaid LN, Brown JV, Micha JP, Lopez KL, et al. Survival rate comparisons amongst cervical cancer patients treated with an open, robotic-assisted or laparoscopic radical hysterectomy: A five year experience. Surg Oncol. 2016 Mar;25(1):66-71.

16. Corrado G, Vizza E, Legge F, Pedone Anchora L, Sperduti I, Fagotti A, et al. Comparison of Different Surgical Approaches for Stage IB1 Cervical Cancer Patients: A Multi-institution Study and a Review of the Literature. Int J Gynecol Cancer Off J Int Gynecol Cancer Soc. 2018 Jun;28(5):1020-8. 17. Bogani G, Cromi A, Serati M, Di Naro E, Uccella S, Donadello N, et al. Predictors of postoperative morbidity after laparoscopic versus open radical hysterectomy plus external beam radiotherapy: a propensity-matched comparison. J Surg Oncol. 2014 Dec;110(7):893-8.

18. Phase III Randomized Trial of Laparoscopic or Robotic vs. Abdominal Radical Hysterectomy in Patients with Early-Stage Cervical Cancer: LACC Trial [Internet]. SGO - SGO 49th Annual Meeting on Women's Cancer. [cited 2018 Jun 11]. Available from:

https://sgo.confex.com/sgo/2018/meetingapp.cgi/Paper/11469

19. Maas CP, Trimbos JB, DeRuiter MC, van de Velde CJH, Kenter GG. Nerve sparing radical hysterectomy: latest developments and historical perspective. Crit Rev Oncol Hematol. 2003 Dec;48(3):271-9.

20. Zullo MA, Manci N, Angioli R, Muzii L, Panici PB. Vesical dysfunctions after radical hysterectomy for cervical cancer: a critical review. Crit Rev Oncol Hematol. 2003 Dec;48(3):287-93. 21. Possover M, Stöber S, Plaul K, Schneider A. Identification and Preservation of the Motoric Innervation of the Bladder in Radical Hysterectomy Type III. Gynecol Oncol. 2000 Nov;79(2):154-7.

22. Benedetti-Panici P, Zullo MA, Plotti F, Manci N, Muzii L, Angioli R. Long-term bladder function in patients with locally advanced cervical carcinoma treated with neoadjuvant chemotherapy and type 3-4 radical hysterectomy. Cancer. 2004 May 15;100(10):2110-7.

23. Chen G-D, Lin L-Y, Wang P-H, Lee H-S. Urinary Tract Dysfunction after Radical Hysterectomy for Cervical Cancer. Gynecol Oncol. 2002 May;85(2):292-7.

24. Liang Z, Chen Y, Xu H, Li Y, Wang D. Laparoscopic nerve-sparing radical hysterectomy with fascia space dissection technique for cervical cancer: description of technique and outcomes. Gynecol Oncol. 2010 Nov;119(2):202-7.

25. Cibula D, Velechovska P, Sláma J, Fischerova D, Pinkavova I, Pavlista D, et al. Late morbidity following nerve-sparing radical hysterectomy. Gynecol Oncol. 2010 Mar;116(3):506-11.

26. Zakashansky K, Chuang L, Gretz H, Nagarsheth NP, Rahaman J, Nezhat FR. A casecontrolled study of total laparoscopic radical hysterectomy with pelvic lymphadenectomy versus radical abdominal hysterectomy in a fellowship training program. Int J Gynecol Cancer Off J Int Gynecol Cancer Soc. 2007 Oct;17(5):1075-82.

27. Magrina JF, Goodrich MA, Weaver AL, Podratz KC. Modified radical hysterectomy: morbidity and mortality. Gynecol Oncol. 1995 Nov;59(2):277-82.

28. Kenter GG, Heintz APM. Surgical treatment of low stage cervical carcinoma: back to the old days? Int J Gynecol Cancer Off J Int Gynecol Cancer Soc. 2002 Oct;12(5):429-34.

29. Kuroda K, Yamamoto Y, Yanagisawa M, Kawata A, Akiba N, Suzuki K, et al. Risk factors and a prediction model for lower limb lymphedema following lymphadenectomy in gynecologic cancer: a hospital-based retrospective cohort study. BMC Womens Health. 2017 Jul 25;17:50.

30. Yost KJ, Cheville AL, Al-Hilli MM, Mariani A, Barrette BA, McGree ME, et al. Lymphedema after surgery for endometrial cancer: prevalence, risk factors, and quality of life. Obstet Gynecol. 2014 Aug;124(2 Pt 1):307-15.

31. Zikan M, Fischerova D, Pinkavova I, Slama J, Weinberger V, Dusek L, et al. A prospective study examining the incidence of asymptomatic and symptomatic lymphoceles following lymphadenectomy in patients with gynecological cancer. Gynecol Oncol. 2015 May 1;137(2):291-8. 32. Querleu D, Leblanc E, Cartron G, Narducci F, Ferron G, Martel P. Audit of preoperative and early complications of laparoscopic lymph node dissection in 1000 gynecologic cancer patients. Am J Obstet Gynecol. 2006 Nov;195(5):1287-92.

33. Persson J, Reynisson P, Borgfeldt C, Kannisto P, Lindahl B, Bossmar T. Robot assisted laparoscopic radical hysterectomy and pelvic lymphadenectomy with short and long term morbidity data. Gynecol Oncol. 2009 May;113(2):185-90.

34. Kruijdenberg CBM, van den Einden LCG, Hendriks JCM, Zusterzeel PLM, Bekkers RLM. Robot-assisted versus total laparoscopic radical hysterectomy in early cervical cancer, a review. Gynecol Oncol. 2011 Mar;120(3):334-9.

35. Querleu D, Planchamp F, Chiva L, Fotopoulou C, Barton D, Cibula D, et al. European Society of Gynaecological Oncology (ESGO) Guidelines for Ovarian Cancer Surgery. Int J Gynecol Cancer. 2017 Sep;27(7):1534.

36. Querleu D, Planchamp F, Chiva L, Fotopoulou C, Barton D, Cibula D, et al. European Society 
of Gynaecologic Oncology Quality Indicators for Advanced Ovarian Cancer Surgery. Int J Gynecol Cancer. 2016 Sep;26(7):1354.

37. Uzan C, Merlot B, Gouy S, Belghiti J, Haie-Meder C, Nickers P, et al. Laparoscopic radical hysterectomy after preoperative brachytherapy for stage IB1 cervical cancer: feasibility, results, and surgical implications in a large bicentric study of 162 consecutive cases. Ann Surg Oncol. 2013 Mar;20(3):872-80. 
Figure 1. Flow-chart of the population study

\section{Senticol I and II cohort $\mathrm{N}=412$}

\section{Radical Hysterectomy $\mathrm{N}=277$}

\section{Final analysis}

$\mathbf{N}=\mathbf{2 4 8}$ 
Figure 2. Recurrence-free survival (A) and overall survival (B) curves of group with and no severe postoperative complications

\section{(A) Reccurence-free survival $p=0.67$}

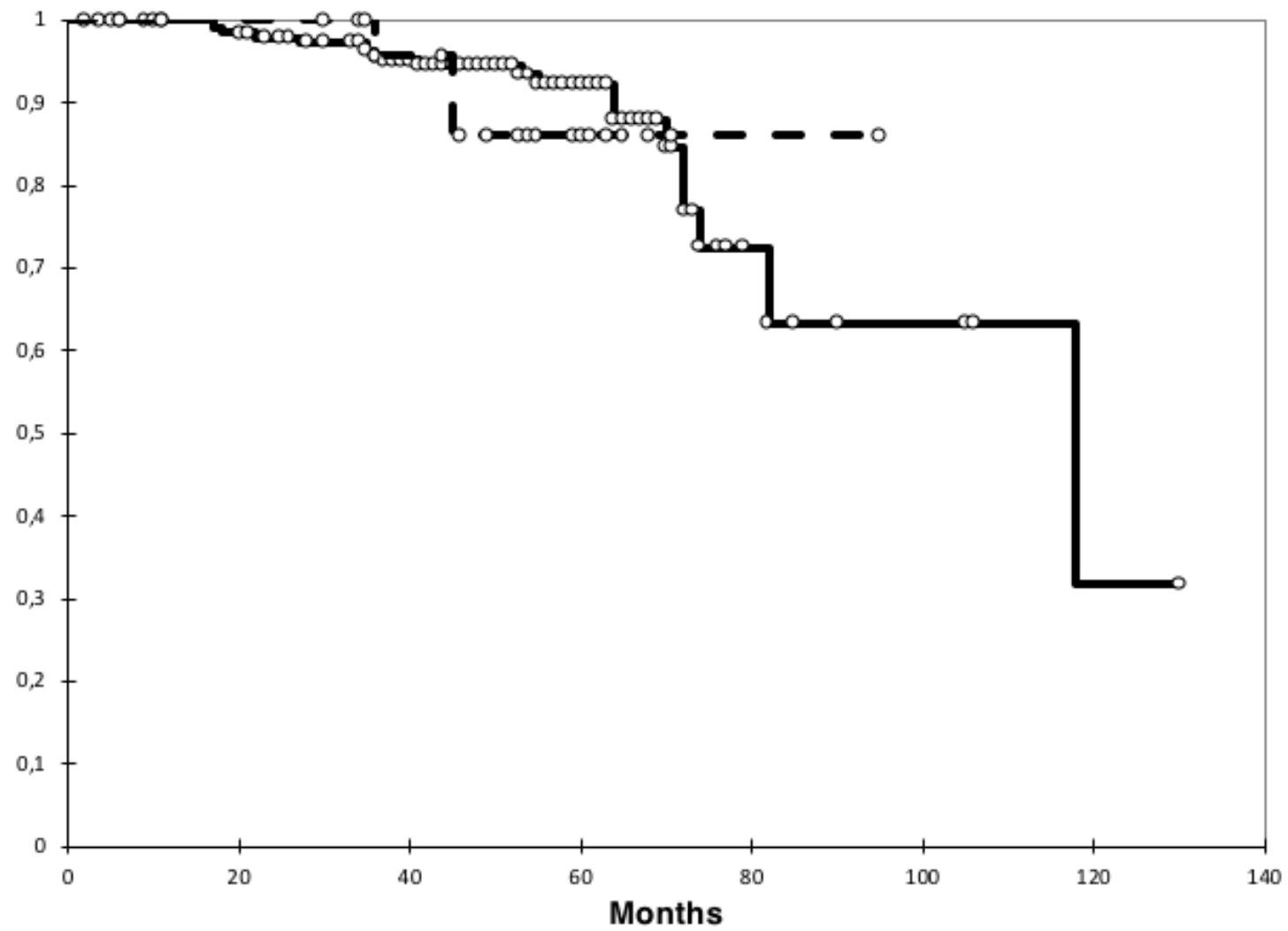




\section{(B) Overall survival}

$p=0.72$

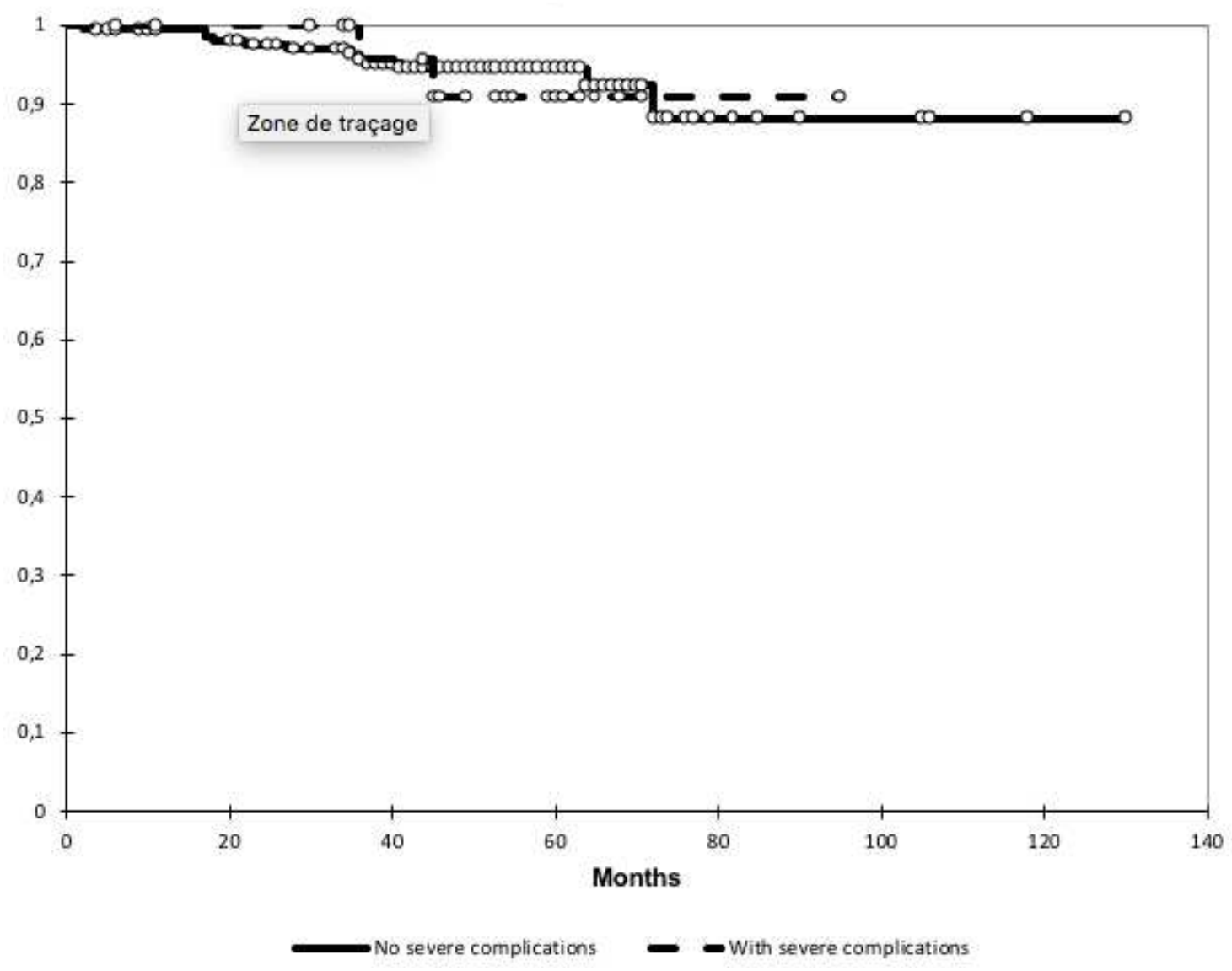


Table 1. Clinicopathologic and surgical characteristics of patients

\begin{tabular}{|c|c|c|}
\hline $\begin{array}{l}\text { Total population } \\
\qquad N=248\end{array}$ & $\begin{array}{c}\mathbf{N} \\
\text { Median }\end{array}$ & $\begin{array}{c}(\%) \\
\text { [range] }\end{array}$ \\
\hline \multicolumn{3}{|l|}{ Age (years) } \\
\hline Median & 44.5 & {$[25-85]$} \\
\hline$<30$ & 8 & $3.2 \%$ \\
\hline $30-60$ & 195 & $78.6 \%$ \\
\hline$>60$ & 45 & $18.1 \%$ \\
\hline \multicolumn{3}{|l|}{ BMI $\left(\mathrm{kg} / \mathrm{m}^{2}\right)$} \\
\hline Median & 22.9 & [14.6-45] \\
\hline$<18,5$ & 15 & $6 \%$ \\
\hline $18,5-25$ & 155 & $62.5 \%$ \\
\hline$<25-30$ & 44 & $17.7 \%$ \\
\hline$>30$ & 34 & $13.7 \%$ \\
\hline \multicolumn{3}{|l|}{ Parity } \\
\hline 0 & 45 & $18.1 \%$ \\
\hline$\geq 1$ & 203 & $81.9 \%$ \\
\hline \multicolumn{3}{|l|}{ Menopausal status } \\
\hline Yes & 84 & $33.9 \%$ \\
\hline No & 164 & $66.1 \%$ \\
\hline \multicolumn{3}{|l|}{ History of previous pelvic surgery } \\
\hline 0 & 128 & $51.6 \%$ \\
\hline 1 & 85 & $34.3 \%$ \\
\hline$\geq 2$ & 35 & $14.1 \%$ \\
\hline \multicolumn{3}{|l|}{ FIGO stage } \\
\hline IA1 with emboli & 6 & $2.4 \%$ \\
\hline IA2 & 14 & $5.6 \%$ \\
\hline IB1 & 220 & $88.7 \%$ \\
\hline IB2 & 1 & $0.4 \%$ \\
\hline IIA & 6 & $2.4 \%$ \\
\hline IIB & 1 & $0.4 \%$ \\
\hline \multicolumn{3}{|l|}{ Histology } \\
\hline Squamous cell carcinoma & 177 & $71.4 \%$ \\
\hline Adenocarcinoma & 62 & $25 \%$ \\
\hline Adenosquamous & 4 & $1.6 \%$ \\
\hline Adenoid kystic carcinoma & 1 & $0.4 \%$ \\
\hline Unknown & 4 & $1.6 \%$ \\
\hline \multicolumn{3}{|l|}{ Presence of LVSI in the biopsy } \\
\hline Yes & 48 & $19.4 \%$ \\
\hline No & 166 & $66.9 \%$ \\
\hline Unknown & 34 & $13.7 \%$ \\
\hline \multicolumn{3}{|l|}{ Tumoral size at preoperative imaging } \\
\hline Median & 15 & {$[0-50]$} \\
\hline Size $<20 \mathrm{~mm}$ & 121 & $48.8 \%$ \\
\hline Size $\geq 20 \mathrm{~mm}$ & 87 & $35.1 \%$ \\
\hline Unknown & 40 & $16.1 \%$ \\
\hline Preoperative LEEP & & \\
\hline
\end{tabular}




\begin{tabular}{|c|c|c|}
\hline Yes & 150 & $60.5 \%$ \\
\hline No & 92 & $37.1 \%$ \\
\hline Unknown & 6 & $2.4 \%$ \\
\hline \multicolumn{3}{|l|}{ Preoperative brachytherapy } \\
\hline Yes & 76 & $30.6 \%$ \\
\hline No & 166 & $66.1 \%$ \\
\hline Unknown & 7 & $2.8 \%$ \\
\hline \multicolumn{3}{|l|}{ Number of step-surgery } \\
\hline 1 & 218 & $87.9 \%$ \\
\hline 2 & 30 & $12.1 \%$ \\
\hline \multicolumn{3}{|l|}{ Type of surgical approach } \\
\hline LARVH & 125 & $50.4 \%$ \\
\hline Laparoscopy & 88 & $35.5 \%$ \\
\hline Laparotomy & 26 & $10.5 \%$ \\
\hline Robot-assisted laparoscopy & 9 & $3.6 \%$ \\
\hline \multicolumn{3}{|l|}{ Type of RH (Querleu-Morrow) } \\
\hline B & 210 & $84.7 \%$ \\
\hline C & 29 & $11.7 \%$ \\
\hline Unknown & 9 & $3.6 \%$ \\
\hline \multicolumn{3}{|l|}{ Nodal staging } \\
\hline SLN alone & 75 & $30.2 \%$ \\
\hline$S L N+P L$ & 157 & $63.3 \%$ \\
\hline $\mathrm{SLN}+\mathrm{PL}+\mathrm{PAL}$ & 16 & $6.5 \%$ \\
\hline Number of SLN per patient & 3 & {$[1-11]$} \\
\hline Number of Nodes per patient if PL done & 13 & [3-72] \\
\hline \multicolumn{3}{|l|}{ Patients with positive SLN } \\
\hline Yes & 27 & $10.9 \%$ \\
\hline No & 215 & $86.7 \%$ \\
\hline Unknown & 6 & $2.4 \%$ \\
\hline \multicolumn{3}{|l|}{ Patients with $\geq 1$ positive node } \\
\hline Yes & 30 & $12.1 \%$ \\
\hline No & 218 & $87.9 \%$ \\
\hline \multicolumn{3}{|l|}{ Final pathologic exam } \\
\hline \multicolumn{3}{|l|}{ Tumor size } \\
\hline \multicolumn{3}{|l|}{ Median } \\
\hline$<20 \mathrm{~mm}$ & 185 & $74.6 \%$ \\
\hline$\geq 20 \mathrm{~mm}$ & 44 & $17.7 \%$ \\
\hline Unknown & 19 & $7.7 \%$ \\
\hline \multicolumn{3}{|l|}{ LVSI } \\
\hline Yes & 76 & $30.6 \%$ \\
\hline No & 172 & $69.4 \%$ \\
\hline \multicolumn{3}{|l|}{ Parametrial invasion } \\
\hline Yes & 10 & $4 \%$ \\
\hline No & 230 & $92.7 \%$ \\
\hline Unknown & 8 & $3.2 \%$ \\
\hline \multicolumn{3}{|l|}{ Vaginal invasion } \\
\hline Yes & 12 & $4.8 \%$ \\
\hline No & 226 & $91.1 \%$ \\
\hline Unknown & 10 & $4 \%$ \\
\hline \multicolumn{3}{|l|}{ Positive margin } \\
\hline Yes & 12 & $4.8 \%$ \\
\hline No & 226 & $91.1 \%$ \\
\hline
\end{tabular}




\begin{tabular}{|ccc|}
\hline Unknown & 10 & $4 \%$ \\
Adjuvant radiotherapy & & $18.5 \%$ \\
Yes & 46 & $79.8 \%$ \\
No & 198 & $1.6 \%$ \\
\hline
\end{tabular}


Table 2. Intraoperative and postoperative complications

\begin{tabular}{|c|c|c|}
\hline $\begin{array}{l}\text { Variable } \\
N=248\end{array}$ & $\mathrm{n}$ & $\%$ \\
\hline \multicolumn{3}{|l|}{ Intraoperative complications } \\
\hline Bladder & 5 & $2 \%$ \\
\hline Ureter & 2 & $0.8 \%$ \\
\hline Vascular & 4 & $1.6 \%$ \\
\hline Other & 5 & $2 \%$ \\
\hline \multicolumn{3}{|l|}{ Severe complications } \\
\hline Vaginal cuff dehiscence & 11 & $4 \%$ \\
\hline Fistula & 7 & $2.8 \%$ \\
\hline Severe abdominal infection & 4 & $1.6 \%$ \\
\hline Hydronephrosis & 3 & $1.2 \%$ \\
\hline Lymphocele drainage & 3 & $1.2 \%$ \\
\hline Hemorragic complications & 2 & $0.8 \%$ \\
\hline Thromboembolic events & 2 & $0.8 \%$ \\
\hline Other & 3 & $1.2 \%$ \\
\hline \multicolumn{3}{|l|}{ Urinary tract complications } \\
\hline Urinary infections (lower and upper tract) & 48 & $19.4 \%$ \\
\hline Dysuria & 17 & $6.9 \%$ \\
\hline Stress urinary incontinence & 14 & $5.6 \%$ \\
\hline Urinary retention & 12 & $4.8 \%$ \\
\hline Hypotonic bladder & 3 & $1.2 \%$ \\
\hline Prolapsus & 1 & $0.4 \%$ \\
\hline Other & 11 & $4.4 \%$ \\
\hline \multicolumn{3}{|l|}{ Lymphovascular complications } \\
\hline Lower limb lymphedema & 36 & $14.5 \%$ \\
\hline Lymphocyst & 14 & $9.3 \%$ \\
\hline Pubic lymphedema & 4 & $1.6 \%$ \\
\hline Inguinal lymphedema & 2 & $0.8 \%$ \\
\hline \multicolumn{3}{|l|}{ Neurologic complications } \\
\hline Genito-femoral nerve & 25 & $10.1 \%$ \\
\hline Obturator nerve & 23 & $9.3 \%$ \\
\hline Lateral femoral cutaneous nerve & 3 & $1.2 \%$ \\
\hline Pudendal nerve & 1 & $0.4 \%$ \\
\hline
\end{tabular}


Table 3. Univariate analysis of risk factors of intraoperative complications

\begin{tabular}{|c|c|c|c|c|c|}
\hline \multirow[t]{2}{*}{ Predictive variable } & \multicolumn{2}{|c|}{$\begin{array}{l}\text { Group with intraoperative } \\
\text { complications } \\
N=16\end{array}$} & \multicolumn{2}{|c|}{$\begin{array}{l}\text { Group without } \\
\text { intraoperative } \\
\text { complications } \\
\quad \mathrm{N}=232\end{array}$} & \multirow[t]{2}{*}{$\boldsymbol{P}$} \\
\hline & $\begin{array}{c}n \\
\text { median }\end{array}$ & $\begin{array}{c}\text { [\%] } \\
\text { [range] }\end{array}$ & $\begin{array}{c}n \\
\text { median }\end{array}$ & $\begin{array}{c}{[\%]} \\
\text { [range] }\end{array}$ & \\
\hline \multicolumn{6}{|l|}{ Type of inclusion center } \\
\hline Type 1 & 6 & $37.5 \%$ & 57 & $24.6 \%$ & \multirow{3}{*}{0.51} \\
\hline Type 2 & 2 & $12.5 \%$ & 33 & $14.2 \%$ & \\
\hline Type 3 & 8 & $50 \%$ & 142 & $61.2 \%$ & \\
\hline \multicolumn{6}{|l|}{ Age [years] } \\
\hline Median & 44 & {$[25-77]$} & 45 & {$[25-85]$} & \multirow{3}{*}{$\begin{array}{c}0.61 \\
0.6\end{array}$} \\
\hline$<45$ & 9 & $56.3 \%$ & 115 & $49.6 \%$ & \\
\hline$\geq 45$ & 7 & $43.8 \%$ & 117 & $50.4 \%$ & \\
\hline \multicolumn{6}{|l|}{ BMI $\left[\mathrm{kg} / \mathrm{m}^{2}\right]$} \\
\hline Median & 27.9 & [19.5 - 39.8] & 22.8 & {$[14.6-45]$} & \multirow[t]{5}{*}{0.001} \\
\hline$<18,5$ & 0 & $0 \%$ & 15 & $6.5 \%$ & \\
\hline $18,5-25$ & 8 & $50 \%$ & 147 & $63.4 \%$ & \\
\hline$<25-30$ & 0 & $0 \%$ & 44 & $19 \%$ & \\
\hline$>30$ & 8 & $50 \%$ & 26 & $11.2 \%$ & \\
\hline \multicolumn{6}{|l|}{ Parity } \\
\hline 0 & 2 & $12.5 \%$ & 43 & $18.5 \%$ & \multirow{2}{*}{0.54} \\
\hline$\geq 1$ & 14 & $87.5 \%$ & 189 & $81.5 \%$ & \\
\hline \multicolumn{6}{|l|}{ Menopausal status } \\
\hline Yes & 6 & $37.5 \%$ & 78 & $33.6 \%$ & \multirow{2}{*}{0.75} \\
\hline No & 10 & $62.5 \%$ & 154 & $66.4 \%$ & \\
\hline \multicolumn{6}{|l|}{$\begin{array}{l}\text { History of previous pelvic } \\
\text { surgery }\end{array}$} \\
\hline 0 & 8 & $50 \%$ & 120 & $51.7 \%$ & \multirow{2}{*}{0.89} \\
\hline$\geq 1$ & 8 & $50 \%$ & 112 & $48.3 \%$ & \\
\hline \multicolumn{6}{|l|}{ FIGO stage } \\
\hline IA1 with emboli - IA2 & 1 & $6.3 \%$ & 19 & $8.2 \%$ & \multirow{3}{*}{0.99} \\
\hline IB1 & 15 & $93.8 \%$ & 205 & $88.4 \%$ & \\
\hline IB2-IIB & 0 & $0 \%$ & 8 & $3.4 \%$ & \\
\hline \multicolumn{6}{|l|}{ Histology } \\
\hline Squamous cell carcinoma & 11 & $68.8 \%$ & $166 / 228$ & $72.8 \%$ & \multirow{3}{*}{0.73} \\
\hline Adenocarcinoma & 5 & $31.2 \%$ & $57 / 228$ & $25 \%$ & \\
\hline Other type & 0 & $0 \%$ & $5 / 228$ & $2.2 \%$ & \\
\hline \multicolumn{6}{|l|}{ Presence of LVSI in the biopsy } \\
\hline Yes & $3 / 14$ & $21.4 \%$ & $45 / 200$ & $22.5 \%$ & \multirow{2}{*}{0.93} \\
\hline No & $11 / 14$ & $78.6 \%$ & $155 / 200$ & $77.5 \%$ & \\
\hline \multicolumn{6}{|l|}{$\begin{array}{l}\text { Tumoral size at preoperative } \\
\text { imaging }\end{array}$} \\
\hline Size $<20 \mathrm{~mm}$ & $6 / 14$ & $42.9 \%$ & 115 & $50.3 \%$ & \multirow{2}{*}{0.23} \\
\hline Size $\geq 20 \mathrm{~mm}$ & $8 / 14$ & $57.1 \%$ & 79 & $40.7 \%$ & \\
\hline Preoperative LEEP & & & & & \\
\hline Yes & 9 & $56.2 \%$ & $141 / 226$ & $62.4 \%$ & \\
\hline No & 7 & $43.8 \%$ & $85 / 226$ & $37.6 \%$ & 0.74 \\
\hline Preoperative brachytherapy & & & & & \\
\hline Yes & 4 & $25 \%$ & $72 / 225$ & $32 \%$ & \\
\hline No & 12 & $75 \%$ & $153 / 225$ & $68 \%$ & 0.56 \\
\hline
\end{tabular}




\begin{tabular}{|c|c|c|c|c|c|}
\hline \multicolumn{6}{|l|}{ Number of step-surgery } \\
\hline 1 & 13 & $81.3 \%$ & 205 & $88.4 \%$ & \multirow{2}{*}{0.4} \\
\hline 2 & 3 & $18.8 \%$ & 27 & $11.6 \%$ & \\
\hline \multicolumn{6}{|l|}{ Type of surgical approach } \\
\hline LARVH & 4 & $25 \%$ & 125 & $52.2 \%$ & \multirow{4}{*}{0.007} \\
\hline Laparoscopy & 6 & $37.5 \%$ & 82 & $35.3 \%$ & \\
\hline Laparotomy & 6 & $37.5 \%$ & 20 & $8.6 \%$ & \\
\hline Robot-assisted laparoscopy & 0 & $0 \%$ & 9 & $3.9 \%$ & \\
\hline \multicolumn{6}{|l|}{ Type of RH (Querleu-Morrow) } \\
\hline B & $14 / 15$ & $93.3 \%$ & $196 / 224$ & $87.5 \%$ & \multirow{2}{*}{0.5} \\
\hline C & $1 / 15$ & $6.7 \%$ & $28 / 224$ & $12.5 \%$ & \\
\hline \multicolumn{6}{|l|}{ Nodal staging } \\
\hline SLN alone & 4 & $25 \%$ & 71 & $30.6 \%$ & \multirow{3}{*}{0.91} \\
\hline SLN + PL & 11 & $68.8 \%$ & 146 & $62.9 \%$ & \\
\hline$S L N+P L+P A L$ & 1 & $6.3 \%$ & 15 & $6.5 \%$ & \\
\hline Number of SLN per patient & 3.5 & {$[1-8]$} & 3 & {$[1-11]$} & \multirow[b]{2}{*}{0.45} \\
\hline $\begin{array}{l}\text { Number of Nodes per patient if } \\
\text { PL done }\end{array}$ & 13.5 & {$[7-36]$} & 13 & {$[3-72]$} & \\
\hline \multicolumn{6}{|l|}{ Patients with positive SLN } \\
\hline Yes & 3 & $18.8 \%$ & 24 & $10.3 \%$ & \multirow{2}{*}{0.3} \\
\hline No & 13 & $81.3 \%$ & 208 & $89.7 \%$ & \\
\hline \multicolumn{6}{|l|}{ Patients with $\geq 1$ positive node } \\
\hline Yes & 3 & $18.8 \%$ & 27 & $11.6 \%$ & \multirow{2}{*}{0.4} \\
\hline No & 13 & $81.3 \%$ & 205 & $88.4 \%$ & \\
\hline \multicolumn{6}{|l|}{ Final pathologic exam } \\
\hline \multicolumn{6}{|l|}{ Tumor size } \\
\hline$<20 \mathrm{~mm}$ & $8 / 15$ & $53.3 \%$ & $177 / 214$ & $82.7 \%$ & \multirow{2}{*}{0.005} \\
\hline$\geq 20 \mathrm{~mm}$ & $7 / 15$ & $46.7 \%$ & $37 / 214$ & $17.3 \%$ & \\
\hline \multicolumn{6}{|l|}{ LVSI } \\
\hline Yes & 5 & $31.3 \%$ & 71 & $30.6 \%$ & \multirow{2}{*}{0.82} \\
\hline No & 11 & $68.8 \%$ & 161 & $69.4 \%$ & \\
\hline \multicolumn{6}{|l|}{ Parametrial invasion } \\
\hline Yes & $3 / 14$ & $21.4 \%$ & $7 / 226$ & $3.1 \%$ & \multirow{2}{*}{0.001} \\
\hline No & $11 / 14$ & $78.6 \%$ & $219 / 226$ & $96.9 \%$ & \\
\hline \multicolumn{6}{|l|}{ Vaginal invasion } \\
\hline Yes & $4 / 14$ & $28.6 \%$ & $8 / 224$ & $3.6 \%$ & $<0.000$ \\
\hline No & $10 / 14$ & $71.4 \%$ & $216 / 224$ & $96.4 \%$ & 1 \\
\hline \multicolumn{6}{|l|}{ Positive margin } \\
\hline Yes & $1 / 15$ & $6.7 \%$ & $11 / 223$ & $4.9 \%$ & \\
\hline No & $14 / 15$ & $93.3 \%$ & $212 / 223$ & $95.1 \%$ & 0.77 \\
\hline
\end{tabular}


Table 4. Univariate analysis of risk factors of severe postoperative complications

\begin{tabular}{|c|c|c|c|c|c|}
\hline \multirow[t]{2}{*}{ Predictive variable } & \multicolumn{2}{|c|}{$\begin{array}{c}\text { Group with } \\
\text { complications } \\
\mathbf{N}=31\end{array}$} & \multicolumn{2}{|c|}{$\begin{array}{l}\text { Group without } \\
\text { complications } \\
N=217\end{array}$} & \multirow[t]{2}{*}{$\boldsymbol{P}$} \\
\hline & $\begin{array}{c}\mathbf{n} \\
\text { median }\end{array}$ & $\begin{array}{c}{[\%]} \\
\text { [range] }\end{array}$ & $\begin{array}{c}n \\
\text { median }\end{array}$ & $\begin{array}{c}{[\%]} \\
\text { [range] }\end{array}$ & \\
\hline \multicolumn{6}{|l|}{ Type of inclusion center } \\
\hline Type 1 & 13 & $23.1 \%$ & 50 & $41.9 \%$ & \multirow{3}{*}{0.05} \\
\hline Type 2 & 5 & $13.8 \%$ & 30 & $16.1 \%$ & \\
\hline Type 3 & 13 & $63.1 \%$ & 137 & $41.9 \%$ & \\
\hline \multicolumn{6}{|l|}{ Age [years] } \\
\hline Median & 45 & [25 - 67] & 44 & [25 - 85] & \multirow{3}{*}{$\begin{array}{l}0.77 \\
0.18\end{array}$} \\
\hline$<45$ & 12 & $38.7 \%$ & 112 & $51.6 \%$ & \\
\hline$\geq 45$ & 19 & $61.3 \%$ & 105 & $48.4 \%$ & \\
\hline \multicolumn{6}{|l|}{ BMI $\left[\mathrm{kg} / \mathrm{m}^{2}\right]$} \\
\hline Median & 22.8 & {$[16.8-36.8]$} & 22.9 & {$[14.6-45]$} & \multirow[t]{5}{*}{0.81} \\
\hline$<18,5$ & 1 & $3.2 \%$ & 14 & $6.4 \%$ & \\
\hline $18,5-25$ & 21 & $67.7 \%$ & 134 & $61.8 \%$ & \\
\hline$<25-30$ & 5 & $16.1 \%$ & 39 & $18 \%$ & \\
\hline$>30$ & 4 & $12.9 \%$ & 30 & $13.8 \%$ & \\
\hline \multicolumn{6}{|l|}{ Parity } \\
\hline 0 & 5 & $16.1 \%$ & 40 & $18.4 \%$ & \multirow{2}{*}{0.76} \\
\hline$\geq 1$ & 26 & $83.9 \%$ & 177 & $81.6 \%$ & \\
\hline \multicolumn{6}{|l|}{ Menopausal status } \\
\hline Yes & 11 & $35.5 \%$ & 73 & $33.6 \%$ & \multirow{2}{*}{0.84} \\
\hline No & 20 & $64.5 \%$ & 144 & $66.4 \%$ & \\
\hline \multicolumn{6}{|l|}{$\begin{array}{l}\text { History of previous pelvic } \\
\text { surgery }\end{array}$} \\
\hline 0 & 17 & $54.8 \%$ & 111 & $51.2 \%$ & \multirow{2}{*}{0.7} \\
\hline$\geq 1$ & 14 & $45.2 \%$ & 106 & $48.8 \%$ & \\
\hline \multicolumn{6}{|l|}{ FIGO stage } \\
\hline IA1 with emboli - IA2 & 3 & $9.7 \%$ & 17 & $7.8 \%$ & \multirow{3}{*}{0.53} \\
\hline IB1 & 28 & $90.3 \%$ & 192 & $88.5 \%$ & \\
\hline IB2-IIB & 0 & $0 \%$ & 8 & $3.7 \%$ & \\
\hline \multicolumn{6}{|l|}{ Histology } \\
\hline Squamous cell carcinoma & 21 & $67.7 \%$ & $156 / 213$ & $73.2 \%$ & \multirow{3}{*}{0.47} \\
\hline Adenocarcinoma & 10 & $32.3 \%$ & $52 / 213$ & $24.4 \%$ & \\
\hline Other type & 0 & $0 \%$ & $5 / 213$ & $2.3 \%$ & \\
\hline \multicolumn{6}{|l|}{ Presence of LVSI in the biopsy } \\
\hline Yes & $6 / 27$ & $22.2 \%$ & $42 / 187$ & $22.5 \%$ & \multirow{2}{*}{0.98} \\
\hline No & $21 / 27$ & $77.8 \%$ & $145 / 187$ & $77.5 \%$ & \\
\hline \multicolumn{6}{|l|}{$\begin{array}{l}\text { Tumoral size at preoperative } \\
\text { imaging }\end{array}$} \\
\hline Size $<20 \mathrm{~mm}$ & $15 / 29$ & $51.7 \%$ & $106 / 179$ & $59.2 \%$ & \multirow{2}{*}{0.45} \\
\hline Size $\geq 20 \mathrm{~mm}$ & $14 / 29$ & $48.3 \%$ & 73179 & $40.8 \%$ & \\
\hline Preoperative LEEP & & & & & \\
\hline Yes & 19 & $61.3 \%$ & 131 & $62.1 \%$ & \\
\hline No & 12 & $38.7 \%$ & 80 & $37.9 \%$ & 0.93 \\
\hline Preoperative brachytherapy & & & & & \\
\hline Yes & 14 & $45.2 \%$ & $62 / 208$ & $29.5 \%$ & \\
\hline No & 17 & $54.8 \%$ & $148 / 208$ & $70.5 \%$ & 0.08 \\
\hline
\end{tabular}




\begin{tabular}{|c|c|c|c|c|c|}
\hline $\begin{array}{l}1 \\
2\end{array}$ & $\begin{array}{c}25 \\
6\end{array}$ & $\begin{array}{l}80.6 \% \\
19.4 \%\end{array}$ & $\begin{array}{c}193 \\
24\end{array}$ & $\begin{array}{l}88.9 \% \\
11.1 \%\end{array}$ & 0.18 \\
\hline \multicolumn{6}{|l|}{ Type of surgical approach } \\
\hline $\begin{array}{c}\text { MIS } \\
\text { Laparotomy }\end{array}$ & $\begin{array}{c}29 \\
2\end{array}$ & $\begin{array}{l}93.6 \% \\
6.4 \%\end{array}$ & $\begin{array}{r}193 \\
24\end{array}$ & $\begin{array}{l}88.9 \% \\
11.1 \%\end{array}$ & 0.43 \\
\hline \multicolumn{6}{|l|}{ Type of RH (Querleu-Morrow) } \\
\hline $\begin{array}{l}B \\
\text { C }\end{array}$ & $\begin{array}{c}26 / 30 \\
4 / 30\end{array}$ & $\begin{array}{l}86.7 \% \\
13.3 \%\end{array}$ & $\begin{array}{l}184 / 209 \\
25 / 209\end{array}$ & $\begin{array}{l}88.1 \% \\
11.9 \%\end{array}$ & 0.83 \\
\hline \multicolumn{6}{|l|}{ Nodal staging } \\
\hline SLN alone & 15 & $48.4 \%$ & 60 & $27.6 \%$ & \multirow{3}{*}{0.06} \\
\hline SLN + PL & 15 & $48.4 \%$ & 142 & $65.4 \%$ & \\
\hline$S L N+P L+P A L$ & 1 & $3.2 \%$ & 15 & $6.9 \%$ & \\
\hline Number of SLN per patient & 3 & {$[2-10]$} & 3 & {$[1-11]$} & 0.21 \\
\hline $\begin{array}{l}\text { Number of Nodes per patient if } \\
\text { PL done } \\
\text { Patients with positive SLN }\end{array}$ & 12 & {$[7-29]$} & 13 & {$[3-72]$} & 0.25 \\
\hline Yes & 3 & $9.7 \%$ & 24 & $11 \%$ & \multirow{2}{*}{0.78} \\
\hline No & 28 & $90.3 \%$ & 193 & $89 \%$ & \\
\hline \multicolumn{6}{|l|}{ Patients with $\geq 1$ positive node } \\
\hline $\begin{array}{l}\text { Yes } \\
\text { No }\end{array}$ & $\begin{array}{c}3 \\
28\end{array}$ & $\begin{array}{c}9.7 \% \\
90.3 \%\end{array}$ & $\begin{array}{c}27 \\
190\end{array}$ & $\begin{array}{l}12.4 \% \\
87.6 \%\end{array}$ & 0.66 \\
\hline \multicolumn{6}{|l|}{ Final pathologic exam } \\
\hline \multicolumn{6}{|l|}{ Tumor size } \\
\hline $\begin{array}{l}<20 \mathrm{~mm} \\
\geq 20 \mathrm{~mm}\end{array}$ & $\begin{array}{c}24 / 30 \\
6 / 30\end{array}$ & $\begin{array}{l}80 \% \\
20 \%\end{array}$ & $\begin{array}{c}161 / 199 \\
38 / 199\end{array}$ & $\begin{array}{l}80.9 \% \\
19.1 \%\end{array}$ & 0.91 \\
\hline \multicolumn{6}{|l|}{ LVSI } \\
\hline Yes & 6 & $19.3 \%$ & 70 & $32 \%$ & \multirow{2}{*}{0.14} \\
\hline $\begin{array}{c}\text { No } \\
\text { Parametrial invasion }\end{array}$ & 25 & $80.7 \%$ & 147 & $68 \%$ & \\
\hline Yes & 3 & $9.7 \%$ & $7 / 209$ & $3.3 \%$ & \multirow{2}{*}{0.1} \\
\hline No & 28 & $90.3 \%$ & 202/209 & $96.7 \%$ & \\
\hline \multicolumn{6}{|l|}{ Vaginal invasion } \\
\hline Yes & $2 / 30$ & $6.7 \%$ & 10/208 & $4.8 \%$ & \multirow{2}{*}{0.66} \\
\hline No & $28 / 30$ & $93.3 \%$ & $198 / 208$ & $95.2 \%$ & \\
\hline \multicolumn{6}{|l|}{ Positive margin } \\
\hline Yes & 3 & $9.7 \%$ & $9 / 207$ & $4.3 \%$ & \multirow{2}{*}{0.21} \\
\hline No & 28 & $90.3 \%$ & 198/207 & $95.7 \%$ & \\
\hline \multicolumn{6}{|l|}{ Adjuvant Radiotherapy } \\
\hline Yes & 7 & $22.6 \%$ & $39 / 213$ & $18.3 \%$ & \multirow{2}{*}{0.57} \\
\hline No & 24 & $77.4 \%$ & $174 / 213$ & $81.7 \%$ & \\
\hline
\end{tabular}

